\title{
POZIOM WIEDZY CHORYCH Z NIESWOISTYMI ZAPALENIAMI JELIT O CHOROBIE I STYLU ŻYCIA
}

\section{THE LEVEL OF PATIENTS' KNOWLEDGE ABOUT THE INFLAMMATORY BOWEL DISEASE AND HEALTHY LIFESTYLE}

\author{
Lucyna Gacek, Grażyna Bączyk, Beata Skokowska, Anna Bielawska, Rozalia Brzezińska \\ Pracownia Praktyki Pielęgniarskiej, Katedra Pielęgniarstwa \\ Uniwersytet Medyczny im. Karola Marcinkowskiego w Poznaniu
}

DOI: https://doi.org/10.20883/pielpol.2017.2

\section{STRESZCZENIE}

Wstęp. W zakres nieswoistych zapaleń jelit wchodzą przede wszystkim dwie jednostki chorobowe: wrzodziejące zapalenie jelita grubego oraz choroba Leśniowskiego-Crohna. Są to choroby przewlekłe, nieuleczalne, z okresami zaostrzeń i remisji, o niewyjaśnionej etiologii. Pierwsze objawy choroby mogą pojawić się w różnym wieku, coraz częściej dotyczą dzieci i młodzieży. Zachorowanie na jedną z chorób wpływa znacząco na dalsze życie człowieka.

Cel. Celem pracy było poznanie poziomu wiedzy chorych z nieswoistymi zapaleniami jelit o własnej chorobie i preferowanym stylu życia.

Materiał i metoda. Grupę badaną stanowiło 67 chorych leczonych z powodu nieswoistych zapaleń jelit. W badaniu wykorzystano kwestionariusz własnego autorstwa zawierający 38 pytań. Część pierwsza dotyczyła danych ogólnych, tj. rozpoznania lekarskiego, płci, wieku, wykształcenia, sytuacji zawodowej, miejsca zamieszkania, stanu cywilnego, sytuacji materialnej/finansowej, czasu trwania choroby. Kolejne pytania odnosity się do wiedzy i zainteresowania ankietowanych własną chorobą. Pytania dotyczyły stylu życia i codziennych sytuacji życiowych: sposobu odżywiania, stosowanych używek, relacji z otoczeniem, sfery seksualnej, aktywności ruchowej i spędzania czasu wolnego. Materiał badawczy opracowano statystycznie.

Wyniki. Badani z nieswoistymi chorobami jelit mają wystarczającą wiedzę na temat własnej choroby, w tym objawów klinicznych, czynników zaostrzających objawy chorobowe oraz metod leczenia. Istnieje potrzeba ciągłego edukowania pacjentów w zakresie zalecanego dla chorych z nieswoistymi zapaleniami jelit stylu życia z uwzględnieniem leczenia dietetycznego i szkodliwości stosowania używek.

Wnioski. Pełna i zadowalająca wiedza pacjentów na temat aspektów klinicznych choroby, czynników zaostrzających przebieg choroby oraz zdrowego stylu życia może przyczynić się do kontrolowania swojego stanu zdrowia, a tym samym - do poprawy jakości i satysfakcji z życia.

SŁOWA KLUCZOWE: pacjent, nieswoiste zapalenia jelit, poziom wiedzy, styl życia.

\section{Wstęp}

W zakres nieswoistych chorób jelit wchodzą: wrzodziejące zapalenie jelita grubego (WZJG, łac. colitis ulcero-

\begin{abstract}
Introduction. The range of inflammatory bowel disease (IBD) primarily consists of two entities: ulcerative colitis (UC) and Crohn's disease (CD). These are chronic incurable diseases, with periods of exacerbation and remission, and with no explained cause. The first symptoms of the disease occur in people of all ages, but more and more often they involve children and young people. Such diseases determine the future way of life of the sick person.

Aim. The aim of this study was to investigate the level of patients' knowledge about their own disease and preferred lifestyle.

Material and methods. The study group consisted of 67 patients treated for inflammatory bowel disease. The study used a questionnaire containing 38 questions. The first part concerned the general data, such as medical diagnosis, gender, age, education, employment status, place of residence, marital status, financial situation and duration of the disease. Other questions referred to the knowledge and interest of the respondents about their own disease. Questions concerned lifestyle and everyday situations, diet, drugs usage, relations, sexuality, physical activity and leisure time. The research material was analyzed statistically.

Results. Paitients with nonspecific bowel disease have enough knowledge about their disease including clinical symptoms, factors aggravating them and treatment. There is a need to continuously educate patients about proper lifestyle, dietary treatment and harmfulness of the use of stimulants.

Conclusions. Full and satisfactory knowledge of the clinical aspects of the disease, factors aggrevating the disease and healthy lifestyle can contribute to the control of their health and thereby improve the quality and life satisfaction.
\end{abstract}

KEYWORDS: patient, inflammatory bowel disease, knowledge, lifestyle.

sa - CU, ang. ulcerative colitis - UC), choroba Leśniowskiego-Crohna (ChLC, ang. Crohn's disease - CD) oraz nieokreślone zapalenia jelit (ang. indeterminate colitis - 
IC). Etiologia i patogeneza nieswoistych zapaleń jelit (NZJ) nie są ostatecznie wyjaśnione. Trwają badania mające na celu poznanie procesów odpowiedzialnych za inicjację oraz podtrzymywanie zapalnych chorób jelit, jednak nadal wiele aspektów tych procesów pozostaje niewyjaśnionych. Uważa się, że w rozwoju NZJ uczestniczą czynniki genetyczne, środowiskowe i immunologiczne [1].

$\mathrm{Na}$ udział czynnika genetycznego wskazuje rodzinne występowanie WZJG i ChLC, obserwowane w 5-10\% przypadków [1]. Najistotniejszym czynnikiem środowiskowym uczestniczącym w patogenezie NZJ są drobnoustroje wchodzące w skład flory bakteryjnej. Zaburzenia ochronnych mechanizmów odpornościowych i regulacyjnych mogą powodować wystąpienie niepożądanych reakcji immunologicznych i rozwój reakcji zapalnych, co prowadzi do uszkodzenia tkanki jelitowej. Ponadto pod wpływem stosowanych z różnych przyczyn antybiotyków zaburzona flora może nasilać objawy NZJ. Badania potwierdzają, że flora bakteryjna w tych jednostkach chorobowych różni się ilościowo i jakościowo od bakterii występujących u osób zdrowych [1-3]. Istotnym czynnikiem sprzyjającym rozwojowi NZJ jest palenie tytoniu. Dodatkowo nikotyna może być też czynnikiem, który przy odpowiedniej podatności genetycznej zdeterminuje rozwój choroby w kierunku WZJG lub ChLC. Badania potwierdzają również, że osoby zaczynające palić w wieku 10-15 lat chorują znacznie częściej na NZJ niż osoby niepalące lub te, które zaczęły palić w późniejszym wieku [4-6]. W przebiegu choroby nie powinno się pomijać czynnika psychicznego. Znaczna liczba pacjentów wiąże wystąpienie pierwszych objawów choroby ze stresem. Z badań wynika, że stres nie wywołuje choroby, może jednak wpłynąć na jej ujawnienie się i przebieg [7]. Przyczyną NZJ jest nadwrażliwość układu immunologicznego, która prowadzi do wywołania reakcji zapalnej i powstania nacieku zapalnego złożonego zarówno z komórek nieswoistej odpowiedzi immunologicznej (granulocyty, monocyty), jak i limfocytów T i B, czego efektem jest uszkodzenie ściany przewodu pokarmowego z upośledzeniem jego funkcji [1, 2]. Nieswoiste zapalenia jelit są częściej rozpoznawane w Europie Zachodniej i Stanach Zjednoczonych niż w Azji czy Afryce. Na podstawie badań epidemiologicznych wysunięto przypuszczenie, że zachorowaniom na NZJ sprzyja dieta typowa dla mieszkańców tych szerokości geograficznych: uboga w błonnik, owoce, warzywa, a bogata w tłuszcze zwierzęce, cukier i oczyszczone węglowodany. W krajach tych zaobserwowano wzrost zachorowalności na ChLC [8].

Światowa Organizacja Zdrowia (WHO), określając styl życia, posługuje się najczęściej formułą Milio, która definiuje styl życia jako „wzory wyborów zachowań spośród alternatywnych możliwości, jakie dostępne są ludziom w zależności od ich sytuacji społeczno-ekonomicznej i łatwości, z jaką są w stanie przełożyć określone zachowania nad inne" [9]. Do zachowań związanych ze zdrowiem zalicza się „wszystkie czynności zmierzające do utrzymania zdrowia lub jego przywrócenia", a także „wszystkie relacje jednostki wywołane pogorszeniem się samopoczucia, występowaniem dolegliwości lub objawów chorobowych" [10]. Poziom wiedzy na temat choroby i przestrzeganie zalecanego stylu życia może determinować stopień odpowiedzialności za stan swojego zdrowia.

Celem pracy było poznanie poziomu wiedzy chorych z nieswoistymi zapaleniami jelit o chorobie i stylu życia zalecanym w chorobie.

Problemy badawcze:

1. Jaki jest i od czego zależy poziom wiedzy na temat własnej choroby osób leczonych z powodu nieswoistych zapaleń jelit?

2. Jaki jest i od czego zależy poziom wiedzy na temat stylu życia osób leczonych z powodu nieswoistych chorób zapalnych jelit?

3. Czym charakteryzuje się styl życia chorych na nieswoiste zapalenia jelit w badanej grupie?

\section{Materiał i metoda}

Grupę badaną stanowiło 67 chorych leczonych z powodu nieswoistych zapaleń jelit w Oddziale Klinicznym Gastroenterologii Żywienia Człowieka i Chorób Wewnętrznych w Szpitalu Klinicznym im. Heliodora Święcickiego Uniwersytetu Medycznego w Poznaniu. Badania przeprowadzono w okresie od stycznia do marca 2013 r.

W badaniu wykorzystano metodę sondażu diagnostycznego, dane zebrano za pomocą autorskiego kwestionariusza ankiety. Kwestionariusz zawierał 38 pytań. Część pierwsza (na którą składało się 10 pytań) dotyczyła danych społeczno-demograficznych: płci, wieku, wykształcenia, sytuacji zawodowej, miejsca zamieszkania, stanu cywilnego, sytuacji materialnej/finansowej oraz klinicznych: rozpoznania lekarskiego, czasu trwania choroby. Część druga (czyli kolejne 28 pytań) odnosiła się do wiedzy i zainteresowania ankietowanych własną chorobą, zalecanego stylu życia oraz zachowań zdrowotnych podejmowanych przez tych pacjentów:sposobu odżywiania, stosowanych używek, relacji z otoczeniem, sfery seksualnej, aktywności ruchowej, spędzania czasu wolnego oraz innych problemów życiowych. W części z pytań można było wybrać jedną z możliwych odpowiedzi. W pięciu pytaniach można było zaznaczyć kilka odpowiedzi. Dwa pytania były otwarte i dotyczyły znajomości czynników zaostrzających przebieg choroby oraz stosowanych aktualnie z powodu choroby leków.

Analiza statystyczna wyników przeprowadzona została za pomocą programu SPSS 16. Do weryfikacji hipotez użyto testu chi-kwadrat. 


\section{Charakterystyka grupy badanej}

W badaniu uczestniczyło 67 chorych, w tym 42 z chorobą Leśniowskiego-Crohna i 25 pacjentów z wrzodziejącym zapaleniem jelita grubego. Kobiety stanowiły $55,2 \%$ ogólnej liczby badanych, mężczyźni - 44,8\%. Najliczniejszą grupę stanowiły osoby w przedziale wieku $30-50$ lat (46\% badanych). Drugą pod względem liczebności grupą byli chorzy poniżej 30. roku życia (42\%). Najmniej liczną grupę reprezentowali badani powyżej 50. roku życia (12\%). Niemal połowa spośród kobiet nie osiągnęła jeszcze 30. roku życia. Wśród mężczyzn dominowali pacjenci w wieku 30-50 lat, stanowili 53,3\% badanych. U 62,2\% kobiet zdiagnozowano chorobę Leśniowskiego-Crohna, natomiast wrzodziejące zapalenie jelita grubego u 37,8\%. Wśród mężczyzn 63,3\% chorowało na chorobę Leśniowskego-Crohna i 36,7\% na wrzodziejące zapalenie jelita grubego.

U 29,9\% badanych choroba trwała krócej niż 2 lata, $28,4 \%$ badanych to osoby chorujące $2-5$ lat, a $25,3 \%$ badanych to osoby chorujące 5-10 lat. Powyżej 10 lat chorowało $16,2 \%$ badanych.

Najliczniejszą grupę stanowiły osoby z wykształceniem wyższym - $41,8 \% ; 28,4 \%$ to badani z wykształceniem średnim. Wykształcenie zawodowe miało $16,4 \%$ badanych, 10,4\% stanowili uczniowie/studenci. Najmniej liczną grupę stanowili badani $z$ wykształceniem podstawowym $-3 \%$.

Wśród ankietowanych 91\% uznało, że głównym źródłem ich wiedzy o chorobie byli lekarze. Drugim niemal równie popularnym źródłem informacji był Internet, $z$ którego korzystało ponad $85 \%$ badanych. Pielęgniarki stanowiły źródło wiedzy dla $40 \%$ chorych, natomiast $38,9 \%$ korzystało z publikacji i ulotek.

\section{Charakterystyka stylu życia badanej grupy}

Aż $70,1 \%$ ankietowanych na pytanie, czy uważa, że prawidłowo się odżywia, odpowiedziało „Tak”. Niemal wszyscy badani (85\%) posiłki spożywali w domu, 82,1\% gotuje posiłki samodzielnie, nieliczni pacjenci (3\%) korzystają z dań gotowych. Co szósty badany (14,9\%) najczęściej jada w stołówkach lub restauracjach. Spośród badanych nikt nie zaznaczył jako najczęstszego miejsca spożywania posiłków restauracji typu fast food.

Wśród ankietowanych zdecydowana większość (58\%) poświęca na aktywność fizyczną nie więcej niż godzinę dziennie. Brak jakiejkolwiek aktywności ruchowej deklaruje niemal co dziesiąty respondent (9\%). Zadowolenie ze sposobu, w jaki spędza swój wolny czas, zadeklarowało $68,7 \%$. Co trzeci ankietowany stwierdzit, że sposób, w jaki spędza wolny czas, jest niezadowalający (31,3\%). Za dobrą własną sprawność fizyczną uznało $43,3 \%$ respondentów.

Tylko $10,4 \%$ badanych pali papierosy, co trzeci z nich stara się ograniczyć ich liczbę (17,9\%). Ponad
$70 \%$ ankietowanych to osoby niepalące. Połowa respondentów $(50,7 \%)$ deklaruje całkowitą abstynencję, $46,3 \%$ pije alkohol okazjonalnie. Dwie osoby przyznały, że spożywają alkohol często.

Ponad połowa ankietowanych twierdzi, że choroby zapalne jelit wpływają na relacje $z$ otoczeniem $(58,2 \%)$. Co czwarty respondent nie wie, czy ma jakikolwiek wpływ na relacje chorego $z$ otoczeniem $(25,4 \%)$. Ponad $64 \%$ ankietowanych unika spotykania się w miejscach, w których mogliby mieć kłopot $z$ dostępem do toalety. Podobnych środków ostrożności nie stosuje $36 \%$ respondentów.

Zadowolenie ze swego życia intymnego deklaruje $52,2 \%$ ankietowanych, natomiast niezadowolonych jest $19,4 \%$. Na pytanie, czy choroby jelit ich zdaniem mają wpływ na życie seksualne, prawie 30\% ankietowanych uznało, że „Tak”, tyle samo respondentów udzieliło odpowiedzi, że choroba nie ma wpływu, a $40 \%$ badanych uznało, że trudno powiedzieć, czy choroby jelit mają wpływ na życie seksualne.

\section{Wiedza pacjentów z nieswoistymi zapaleniami jelit o chorobie}

Ankietowani w $91 \%$ prawidłowo odpowiedzieli, że wrzodziejące zapalenie jelita grubego i choroba Leśniowskiego-Crohna to choroby przewlekłe i nieuleczalne. Na pytanie dotyczące przyczyn choroby badany mógł zaznaczyć kilka odpowiedzi (Tabela 1). W badanej grupie $56,7 \%$ respondentów wiedziało, że wśród przyczyn występowania choroby są czynniki środowiskowe i immunologiczne, na czynniki genetyczne wskazało $49,3 \%$ badanych, błędy dietetyczne wskazało $43,3 \%$ pacjentów, niehigieniczny tryb życia - 26,9\%, wirusy i bakterie $-16,4 \%$ badanych. Większość respondentów $(80,6 \%)$ prawidłowo wskazała, że przyczyna ich choroby nie jest ostatecznie poznana.

Tabela 1. Przyczyny wystąpienia nieswoistych zapaleń jelit według badanych pacjentów

Table 1. The cause of inflammatory bowel disease according to the patients studied

\begin{tabular}{ccc}
\hline Przyczyny NZJ/Grounds of IBD & $\begin{array}{c}\text { Liczba odpowiedzi/ } \\
\text { Number of answers }\end{array}$ & Procent/Percent \\
\hline $\begin{array}{c}\text { Czynniki genetyczne/Genetic factors } \\
\text { Czynniki środowiskowe i immunolo- } \\
\text { giczne/Environmental and immuno- } \\
\text { logical factors }\end{array}$ & 33 & 49,3 \\
$\begin{array}{c}\text { Wirusy, bakterie/Viruses, bacteria } \\
\text { Błędy dietetyczne/Diet mistakes } \\
\text { Niehigieniczny tryb życia/ } \\
\text { Unhygienic lifestyle }\end{array}$ & 11 & 56,7 \\
$\begin{array}{c}\text { Przyczyna nie jest ostatecznie pozna- } \\
\text { na/Cause unknown }\end{array}$ & 18 & 16,4 \\
\hline
\end{tabular}

Źródło: opracowanie własne

Source: author's own analysis 
Przy pytaniu o najczęstsze objawy nieswoistych zapaleń jelit umieszczono tylko poprawne odpowiedzi. Do objawów najczęściej wskazywanych przez pacjentów należały: biegunka (92,5\%), ból brzucha $(83,6 \%)$, spadek masy ciała $(76,1 \%)$, krew w stolcu $(70,1 \%)$, osłabienie $(68,7 \%)$ i anemia (46,3\%). Obrzęki jako objaw NZJ wskazało tylko $13,4 \%$ chorych.

$\mathrm{Na}$ pytanie dotyczące możliwości posiadania potomstwa przez osobę chorą na nieswoiste zapalenia jelit 61,2\% ankietowanych odpowiedziało prawidłowo, że mogą posiadać potomstwo, $6 \%$ badanych było zdania, że kobieta powinna przerwać leczenie farmakologiczne na czas ciąży, a 3\% uznało, że w ogóle nie powinna mieć dzieci.

Wiedza kobiet i mężczyzn na temat możliwości urodzenia zdrowego dziecka przez kobietę chorą na NZJ różni się istotnie statystycznie ( $p=0,002)$ (Tabela 2 ). Kobiety zdecydowanie częściej świadome były, że mogą urodzić zdrowe dzieci. Odpowiedzi takiej udzieliło ponad $78 \%$ kobiet i $40 \%$ mężczyzn.

Tabela 2. Wiedza kobiet i mężczyzn na temat możliwości posiadania potomstwa

Table 2. Knowledge about the possibility of having children by sex

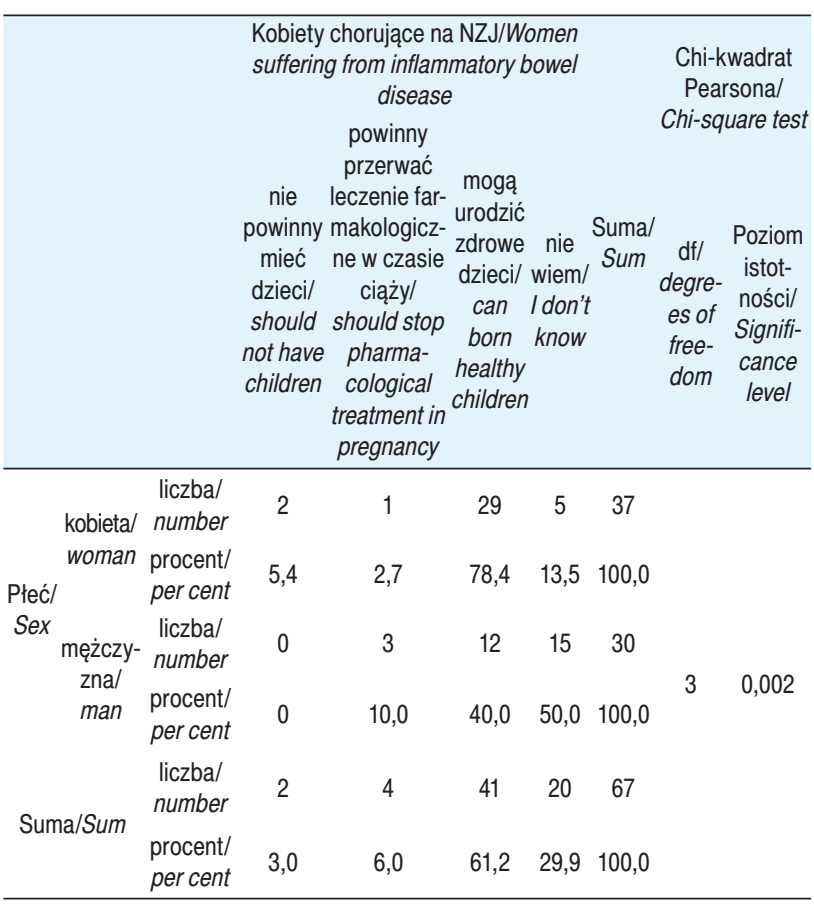

Źródło: opracowanie własne

Source: author's own analysis
Badanym zadano pytanie, czy sytuacje stresowe mogą przyczynić się do zaostrzenia objawów choroby - 76,7\% mężczyzn oraz 91,9\% kobiet odpowiedziało prawidłowo, że stres ma wpływ na przebieg choroby. Odpowiedzi „Nie wiem” zdecydowanie częściej udzielali mężczyźni (26,6\%). Analiza testem chi-kwadrat nie wykazała istnienia różnic pomiędzy zmiennymi.

$\mathrm{Na}$ pytanie, czy nieswoiste zapalenia jelit są przeciwwskazaniem do podejmowania aktywności ruchowej, odpowiedzi były zróżnicowane. Istnieje statystycznie istotna zależność ( $p=0,00044$ przy poziomie istotności $p<0,001)$ pomiędzy odpowiedzią na pytanie o to, czy choroba jest przeciwwskazaniem do aktywności ruchowej, a wykształceniem badanych. Najwięcej prawidłowych odpowiedzi, że choroba, na którą cierpią, nie stanowi przeciwwskazania do podejmowania aktywności ruchowej, zaznaczyli ankietowani z wykształceniem wyższym - 85,7\%, oraz średnim - 84,2\%. Częściej niepoprawnej odpowiedzi udzielali badani z wykształceniem zawodowym (54,5\%) oraz uczniowie i studenci (28,6\%).

Na pytanie, jak badany ocenia swój poziom wiedzy o NZJ, 59,7\% odparło, że jest on wystarczający, $11,9 \%$ uznało go za wysoki, a 20,9\% - za niski.

\section{Wiedza o stylu życia zalecanym dla chorych z NZJ}

Na pytanie dotyczące samooceny posiadanej wiedzy na temat diety w NZJ 14,9\% ankietowanych odpowiedziało, że poziom ich wiedzy jest wysoki, 58,2\% - że wystarczający, za niski uznało go 13,4\% i tyle samo badanych nie potrafiło określić, jaka jest ich wiedza dotycząca diety w chorobach jelit. Na pytanie dotyczące wiedzy na temat zaleceń żywieniowych w chorobie jelit 95,5\% chorych odpowiedziało poprawnie, że podczas nasilenia objawów należy stosować dietę lekkostrawną, 7,5\% badanych nie wiedziało, że nie powinni spożywać wszystkich rodzajów owoców w czasie nasilenia objawów choroby; 58,2\% respondentów wiedziało o konieczności ograniczenia spożycia mleka w diecie, a 49,3\%, że należy zmniejszyć ilość błonnika, natomiast 40,3\% osób zaznaczyło, że trzeba zwiększyć spożycie wody oraz ograniczać ilość wypijanej kawy i herbaty (38,8\%). Tylko 4,5\% badanych wybrało błędną odpowiedź, uznając, że dieta nie ma żadnego znaczenia, jeżeli przyjmują zlecone przez lekarza leki (Tabela 3). 
Tabela 3. Wiedza pacjentów o diecie zalecanej w chorobie jelit Table 3. Patients' knowledge about diet recommended in bowel disease

\begin{tabular}{|c|c|c|}
\hline $\begin{array}{l}\text { Sugerowane odpowiedzi dotyczące wiedzy na temat } \\
\text { diety/Suggested answers on knowledge about diet }\end{array}$ & $\begin{array}{l}\text { Liczba pra- } \\
\text { widłowych } \\
\text { odpowie- } \\
\text { dzi wg } \\
\text { respon- } \\
\text { dentów*/ } \\
\text { Number of } \\
\text { answers }\end{array}$ & $\begin{array}{l}\text { Pro- } \\
\text { cent/ } \\
\text { Per } \\
\text { cent }\end{array}$ \\
\hline $\begin{array}{l}\text { Podczas nasilenia się objawów należy stosować } \\
\text { dietę lekkostrawną/ln case of worsening symptoms } \\
\text { light diet is recommended }\end{array}$ & 64 & 95,5 \\
\hline $\begin{array}{c}\text { W chorobach jelit wskazane jest zwiększenie spoży- } \\
\text { cia wody/In bowel disease increased intake of water is } \\
\text { recommended }\end{array}$ & 27 & 40,3 \\
\hline $\begin{array}{l}\text { Należy ograniczyć ilość mleka w swojej diecie/ } \\
\text { Limited intake of milk is recommended }\end{array}$ & 39 & 58,2 \\
\hline $\begin{array}{l}\text { Podczas nasilenia się objawów należy ograniczyć } \\
\text { spożywanie produktów zawierających błonnik/In case } \\
\text { of worsening symptoms intake of products containing } \\
\text { dietary fibre should be limited }\end{array}$ & 33 & 49,3 \\
\hline $\begin{array}{l}\text { Kawa i herbata mogą wywoływać biegunkę/ } \\
\text { Coffee and tea may cause diarrhea }\end{array}$ & 26 & 38,8 \\
\hline $\begin{array}{c}\text { Podczas nasilenia się objawów można spożywać } \\
\text { wszystkie owoce bez wyjątku/ln case of worsening } \\
\text { symptoms one can eat all kinds of fruits }\end{array}$ & 5 & 7,5 \\
\hline $\begin{array}{l}\text { Dieta nie ma znaczenia, jeżeli regularnie przyjmuje } \\
\text { zlecone przez lekarza leki/lf one takes all prescribed } \\
\text { medications, diet does not make any difference }\end{array}$ & 3 & 4,5 \\
\hline
\end{tabular}

* Każdy z chorych mógł zaznaczyć więcej niż jedną odpowiedź

Źródło: opracowanie własne

Source: author's own analysis

W celu analizy stylu życia pacjentów z nieswoistymi chorobami zapalnymi jelit poproszono pacjentów o ponowne rozwiązanie tabeli, z tym że mieli odpowiadać teraz „Tak - stosuję się do wytycznych dotyczących prawidłowego postępowania żywieniowego" lub "Nie - nie stosuję się do nich” (Tabela 4). W każdym punkcie było więcej osób deklarujących przestrzeganie prawidłowej diety niż chorych, którzy nie stosowali się do zaleceń. Najwięcej osób stosowato prawidłowo dietę lekkostrawną w trakcie zaostrzenia choroby $(67,16 \%)$, unikało nadmiaru spożywania kawy i herbaty $(67,16 \%)$ oraz ograniczało mleko w diecie $(64,18 \%)$.
Tabela 4. Deklarowany przez badanych chorych sposób żywienia w chorobie jelit

Table 4. Stated nutrition in bowel disease according to the patients studied

\begin{tabular}{|c|c|c|c|}
\hline \multirow[t]{2}{*}{$\begin{array}{l}\text { Stwierdzenia dotyczące diety } \\
\text { w chorobie/ } \\
\text { Statements about diet in disease }\end{array}$} & \multicolumn{2}{|c|}{$\begin{array}{l}\text { Czy uważasz, że } \\
\text { prawidłowo się } \\
\text { odżywiasz?*IDo } \\
\text { you think that you } \\
\text { eat healthy? }\end{array}$} & \multirow[t]{2}{*}{$\begin{array}{c}\text { Suma/ } \\
\text { Sum }\end{array}$} \\
\hline & Nie/No & Tak/Yes & \\
\hline $\begin{array}{l}\text { Podczas nasilenia się objawów należy stoso- } \\
\text { wać dietę lekkostrawną/In case of worsening } \\
\text { symptoms light diet is recommended }\end{array}$ & $\begin{array}{c}18 \\
26,86 \%\end{array}$ & $\begin{array}{c}45 \\
67,16 \%\end{array}$ & 63 \\
\hline $\begin{array}{l}\text { W chorobach jelit wskazane jest zwięk- } \\
\text { szenie spożycia wody/ln bowel disease } \\
\text { increased intake of water is recommended } \\
\text { Należy ograniczyć ilość mleka w swojej die- } \\
\text { cie/Limited intake of milk is recommended }\end{array}$ & $\begin{array}{c}11 \\
16,42 \%\end{array}$ & $\begin{array}{c}15 \\
22,39 \%\end{array}$ & 26 \\
\hline $\begin{array}{c}\text { Podczas nasilenia się objawów należy ogra- } \\
\text { niczyć spożywanie produktów zawierających } \\
\text { błonnik/ln case of worsening symptoms intake } \\
\text { of products containing dietary fibre should } \\
\quad \text { be limited } \\
\text { Kawa i herbata mogą wywoływać biegunkę/ } \\
\text { Coffee and tea may cause diarrhea }\end{array}$ & $\begin{array}{c}14 \\
20,89 \%\end{array}$ & $\begin{array}{c}24 \\
35,82 \%\end{array}$ & 38 \\
\hline $\begin{array}{c}\text { Podczas nasilenia się objawów można } \\
\text { spożywać wszystkie owoce bez wyjątku/ln } \\
\text { case of worsening symptoms one can eat } \\
\text { all kinds of fruits }\end{array}$ & $\begin{array}{c}8 \\
11,94 \%\end{array}$ & $\begin{array}{c}24 \\
35,82 \%\end{array}$ & 32 \\
\hline $\begin{array}{l}\text { Podczas nasilenia się objawów należy stoso- } \\
\text { wać dietę lekkostrawną/In case of worsening } \\
\text { symptoms light diet is recommended } \\
\text { W chorobach jelit wskazane jest zwięk- } \\
\text { szenie spożycia wody/ln bowel disease } \\
\text { increased intake of water is recommended }\end{array}$ & $\begin{array}{c}7 \\
10,43 \%\end{array}$ & $\begin{array}{c}18 \\
26,87 \%\end{array}$ & 25 \\
\hline $\begin{array}{l}\text { Należy ograniczyć ilość mleka w swojej die- } \\
\text { cie/Limited intake of milk is recommended } \\
\text { Podczas nasilenia się objawów nale- } \\
\text { ży ograniczyć spożywanie produktów } \\
\text { zawierajajcych błonnik/In case of worsening } \\
\text { symptoms intake of products containing } \\
\text { dietary fibre should be limited }\end{array}$ & $\begin{array}{c}19 \\
28,36 \%\end{array}$ & $\begin{array}{c}43 \\
64,18 \%\end{array}$ & 62 \\
\hline $\begin{array}{l}\text { Kawa i herbata mogą wywoływać biegunkę/ } \\
\text { Coffee and tea may cause diarrhea }\end{array}$ & $\begin{array}{c}18 \\
26,37 \%\end{array}$ & $\begin{array}{c}45 \\
67,16 \%\end{array}$ & 63 \\
\hline
\end{tabular}

* W kolumnach podano liczbę całkowitą badanych odpowiadających na twierdzenie oraz ich wartość procentową względem całej grupy badanej ( $N=67)$; nie wszyscy chorzy odpowiadali na każde pytanie

Źródło: opracowanie własne

Source: author's own analysis

Odpowiadając na pytanie, czy palenie papierosów szkodzi w chorobach NZJ, 44,8\% respondentów zgodziło się z tym, że palenie papierosów jest szkodliwe, $10,4 \%$ odpowiedziało, że nie ma wpływu, a aż $44,8 \%$ odpowiedziało, iż nie wiedzą, że palenie papierosów ma szkodliwy wpływ na przebieg choroby (Tabela 5). Wykazano statystycznie istotną zależność $(p=0,032$ przy poziomie istotności $p<0,05)$ pomiędzy wiekiem respondentów a odpowiedzią na to pytanie. Najwięcej, bo aż $87,5 \%$, badanych powyżej 50 . roku życia uznało szkodliwy wpływ palenia papierosów na przebieg i leczenie NZJ. W grupie $30-50$ lat 39,3\% badanych było 
podobnego zdania. Najmłodsze osoby, poniżej 30. roku życia, odpowiadały najczęściej $(57,1 \%)$, że nie wiedzą, czy palenie papierosów ma wpływ na choroby jelit.

Tabela 5. Wiedza na temat wpływu palenia papierosów na NZJ z uwzględnieniem wieku

Table 5. Knowledge about the effects of smoking on IBD by age

\begin{tabular}{|c|c|c|c|c|c|c|c|}
\hline & & $\begin{array}{r}\mathrm{Cz} \\
\mathrm{zda} \\
\mathrm{pa} \\
\text { wpły } \\
\text { jelit } \\
\text { that s } \\
\text { effec }\end{array}$ & $\begin{array}{l}\text { y Pani/ } \\
\text { niem p } \\
\text { pierosó } \\
\text { /w na c } \\
\text { ?/Do yo } \\
\text { mokin } \\
\text { ct on in } \\
\text { diseas }\end{array}$ & $\begin{array}{l}\text { Dana } \\
\text { alenie } \\
\text { w ma } \\
\text { noroby } \\
\text { uthink } \\
\text { has an } \\
\text { estinal } \\
\text { s? }\end{array}$ & Suma/ & $\begin{array}{l}\text { Chi-kv } \\
\text { Pears } \\
\text { Chi-squ }\end{array}$ & $\begin{array}{l}\text { wadrat } \\
\text { sona/ } \\
\text { tare test }\end{array}$ \\
\hline & & $\begin{array}{l}\text { Tak/ } \\
\text { Yes }\end{array}$ & $\begin{array}{l}\mathrm{Nie} / \\
\text { No }\end{array}$ & $\begin{array}{c}\mathrm{Nie} \\
\text { wiem/ } \\
\text { Don't } \\
\text { know }\end{array}$ & & $\begin{array}{l}\text { df/ } \\
\text { degrees } \\
\text { of } \\
\text { freedom }\end{array}$ & $\begin{array}{c}\text { istotno- } \\
\text { ści/ } \\
\text { Signifi- } \\
\text { cance } \\
\text { level } \\
(\mathrm{p}<0,05)\end{array}$ \\
\hline$<30$ & $\begin{array}{l}\text { liczba/ } \\
\text { number }\end{array}$ & 11 & 1 & 16 & 28 & 4 & 0,032 \\
\hline & $\begin{array}{l}\text { procent/ } \\
\text { per cent }\end{array}$ & 39,3 & 3,6 & 57,1 & 100,0 & & \\
\hline Wiek/ $30-50$ & $\begin{array}{l}\text { liczba/ } \\
\text { number }\end{array}$ & 12 & 5 & 13 & 30 & & \\
\hline Age & $\begin{array}{l}\text { procent/ } \\
\text { per cent }\end{array}$ & 40,0 & 16,7 & 43,3 & 100,0 & & \\
\hline 50 & $\begin{array}{l}\text { liczba/ } \\
\text { number }\end{array}$ & 7 & 1 & 0 & 8 & & \\
\hline & $\begin{array}{l}\text { procent/ } \\
\text { per cent }\end{array}$ & 87,5 & 12,5 & 0 & 100,0 & & \\
\hline Suma/Sum & $\begin{array}{l}\text { liczba/ } \\
\text { number }\end{array}$ & 30 & 7 & 29 & 66 & & \\
\hline & $\begin{array}{l}\text { procent/ } \\
\text { per cent }\end{array}$ & 45,5 & 10,6 & 43,9 & 100,0 & & \\
\hline
\end{tabular}

Źródło: opracowanie własne

Source: author's own analysis

Na pytanie, czy picie alkoholu wpływa negatywnie na przebieg choroby, 49,3\% ankietowanych odpowiedziało, że zdaje sobie sprawę ze szkodliwego wpływu alkoholu na chorobę, 38,8\% stwierdziło, że nie dysponuje wiedzą na ten temat, a $11,9 \%$ badanych zaprzeczyło istnieniu szkodliwego wpływu.

\section{Dyskusja}

Celem przeprowadzonych badań było poznanie wiedzy chorych na temat nieswoistych chorób zapalnych jelit, prawidłowego stylu życia, jaki chorzy z chorobą Leśniowskiego-Crohna czy WZJG powinni prowadzić, oraz czy badani rzeczywiście taki styl życia prowadzili. Na podstawie otrzymanych wyników można wnioskować, że wiedza chorych na temat zarówno samej choroby, jak i prawidłowego stylu życia jest prawidłowa. Większość badanej grupy chorych definiuje swoją chorobę prawidłowo, jako przewlekłą, nieuleczalną, z okresami zaostrzeń i remisji, o niewyjaśnionej etiologii. Potrafią wskazać najczęstsze objawy choroby i czynniki szkodliwe w chorobach jelit. Większość pacjentów jest przekonana, że odżywia się prawidłowo. Potwierdza to fakt, że niemal wszyscy ankietowani posiłki przyrządzają samodzielnie, w domu, korzystając ze świeżych produktów pozbawionych konserwantów i zalecanych w chorobach jelit. Nikt nie podawał, że korzysta z barów i spożywa potrawy typu fast food, w których zawarty jest tłuszcz używany wielokrotnie do smażenia. Jednak nie wszystkie odpowiedzi badanych dotyczące stosowanej przez nich diety wskazują, że przestrzegają oni zaleceń dietetycznych W literaturze [11, 13] określa się zasady żywienia, które mają za zadanie prawidłowo wpływać na stan fizyczny chorego w różnych fazach choroby. $Z$ diety chorego należy wyłączyć produkty źle tolerowane, które wywołują lub nasilają dolegliwości. Zaleca się unikać mocnej herbaty i kawy, ponieważ stymulują kurczliwość jelit, tym samym mogą nasilać biegunkę. Zaleca się również unikanie pokarmów o dużej zawartości siarki, np. pełnowartościowego mleka, jaj, sera żółtego, mięsa, warzyw kapustowatych, wina, produktów ze sztucznymi barwnikami i konserwantami, ponieważ wpływają na produkcję nieprawidłowego śluzu jelitowego i w konsekwencji uszkodzenie jelita. Wśród badanych pacjentów nie wszyscy wiedzieli, że wskazane jest zwiększenie spożycia wody, że należy ograniczyć spożycie mleka i błonnika, że kawa i herbata mogą wywoływać biegunkę lub że nie wszystkie owoce można spożywać podczas nasilenia objawów choroby [11-13]. Badań dotyczących oceny poziomu wiedzy pacjentów z nieswoistymi zapaleniami jelit w polskim piśmiennictwie jest niewiele. $\mathrm{Na}$ uwagę zasługuje badanie przeprowadzone przez Perek i Cepuch w grupie młodzieży chorej na nieswoiste zapalenie jelit [16]. Według badaczek młodzież wykazuje zainteresowanie swoim stanem zdrowia, ma niezbędną wiedzę, aby w pełni uczestniczyć w leczeniu choroby. Wyniki badań własnych oraz Perek i Cepuch są zbliżone zwłaszcza w zakresie znajomości przyczyn choroby, zaleceń żywieniowych, szkodliwości stosowania używek, pomimo że badano inną grupę wiekową. Płeć, wiek, wykształcenie czy czas trwania choroby ankietowanych w badanej grupie nie wpływa na poziom wiedzy na temat własnej choroby.

Ponad połowa badanych deklarowała, że nie pali papierosów lub porzucili nałóg w przeszłości. Niepokojący jest brak wiedzy wśród chorych palących o wpływie palenia papierosów na ich chorobę (71\%). O szkodliwości palenia przekonane są przede wszystkim osoby ograniczające palenie oraz te, które palenie rzuciły. Również pojawia się statystycznie istotna zależność pomiędzy wiekiem respondentów a odpowiedzią 
na pytanie o wpływ palenia na choroby jelit. O tym, że palenie ma szkodliwy wpływ na choroby jelit, wie $88 \%$ badanych powyżej 50. roku życia. Chorzy w tym wieku znacznie ograniczają palenie lub całkiem rezygnują z nałogu. Nadal trwają badania na temat wpływu palenia tytoniu na przebieg nieswoistych zapaleń jelit. Dotychczasowe wyniki wskazują na różnice pomiędzy wpływem tytoniu u chorych z chorobą Leśniowskiego-Crohna, który jest negatywny, a reakcją na tytoń chorych z wrzodziejącym zapaleniem jelita grubego, która w niektórych przypadkach łagodzi jelitowe objawy choroby [4, 5]. Docierające do pacjentów informacje mogą przyczynić się do ich dezorientacji w tym zakresie i sprawa ta wymaga zaangażowania ze strony specjalistów, czyli personelu medycznego, który poprawnie zweryfikuje ich wiedzę.

$\mathrm{Na}$ podstawie odpowiedzi zawartych w kwestionariuszu i po ich analizie można stwierdzić, że istotny czynnik środowiskowy, jakim jest stres w życiu badanych osób, słusznie uznawany jest przez badaczy za przyczynę choroby lub czynnik zaostrzający jej przebieg. Mawdsley i wsp., badając efekty wpływu stresu psychologicznego na odpowiedź immunologiczną u chorych na nieaktywną postać wrzodziejącego zapalenia jelita grubego, wykazali, że na skutek działania ostrego stresu może dochodzić do indukcji systemowej i śluzówkowej reakcji zapalnej, co może być powodem zaostrzenia przebiegu choroby [7]. Większość chorych wie, że czynnik genetyczny może być przyczyną NZJ, ale mają świadomość, że nie jest to przeciwwskazanie do posiadania potomstwa i że kobieta może urodzić zdrowe dziecko. Istotne różnice na ten temat pojawiły się między kobietami a mężczyznami - kobiety zdecydowanie częściej były świadome faktu, że mogą urodzić zdrowe dzieci. Najnowsze zalecenia, w tym opracowane przez European Crohn's and Colitis Organisation (ECCO), podkreślają, że planowanie ciąży ma fundamentalne znaczenie, gdyż zapłodnienie powinno nastąpić w okresie remisji klinicznej. Wówczas zarówno płodność, jak i sam przebieg ciąży nie różnią się zasadniczo u pacjentek z NZJ w porównaniu do populacji ogólnej [14].

Wystąpienie choroby prawdopodobnie przyczyniło się do opinii wśród ponad połowy ankietowanych, że nieswoiste zapalenia jelit wpływają na relacje $z$ otoczeniem. Pilne i częste korzystanie z toalety, pobyty w szpitalu w związku z chorobą oraz ograniczenia żywieniowe mogą wpływać niekorzystnie na relacje interpersonalne. Pokrywa się to z procentem osób badanych, które unikają uczestniczenia w spotkaniach odbywających się w miejscach, gdzie nie ma bliskiego dostępu do toalety. Z przeprowadzonych badań wynika również, że połowa respondentów deklaruje zadowolenie ze swego życia intymnego. O zadowoleniu mówi też niemalże 80\% chorych w kontekście spędzania swojego czasu wolnego, preferowaną formą wypoczynku wśród badanych chorych są spotkania towarzyskie. Wśród ankietowanych zdecydowana większość poświęca na aktywność ruchową nie więcej niż godzinę dziennie i podobna liczba osób swoją sprawność fizyczną ocenia jako bardzo dobrą. Tylko 10\% przepytanych osób jest niezadowolonych ze swojej sprawności fizycznej.

W badaniu wykazano, że popularnym źródłem wiedzy o chorobie są łatwo dostępny Internet oraz lekarz. Z powyższych obserwacji można wysunąć wniosek, że chorzy wiedzą, gdzie szukać informacji o chorobie i możliwości te wykorzystują. Informowanie pacjentów przez personel medyczny jest niewątpliwie ważnym elementem w procesie leczenia wszystkich chorych w tym chorych z nieswoistymi zapaleniami jelit. Istnieje potrzeba stałego edukowania pacjentów w zakresie klinicznym choroby i zalecanego stylu życia.

\section{Wnioski}

1. Pacjenci z nieswoistymi chorobami zapalnymi jelit wykazują wysoki poziom wiedzy na temat swojej jednostki chorobowej. Na wszystkie pytania zdecydowana większość chorych odpowiadała prawidłowo.

2. Głównym źródłem wiedzy pacjenta na temat nieswoistych zapaleń jelit są personel medyczny (przede wszystkim lekarz) oraz Internet. Wynika z tego, że pacjenci braki w informacjach uzyskanych głównie od lekarzy uzupełniają, korzystając z nie zawsze pewnych źródeł internetowych, a nie otrzymują ich od specjalistów.

3. Analiza wpływu danych demograficznych wykazała różnice dotyczącą wiedzy na temat posiadania potomstwa. Kobiety były bardziej świadome braku ograniczeń niż mężczyźni, co może wynikać z faktu, że to one ponoszą ciężar biologicznego utrzymania ciąży i porodu.

4. Wykazano, że istnieje zależność pomiędzy wykształceniem (wyższym) a aktywnością ruchową. Osoby z wyższym wykształceniem mają wiedzę o dostępie do różnych źródeł informacji, wykazują większą świadomość informacyjną.

5. Analiza statystyczna wskazała, że osoby po 50. roku życia miały pełną świadomość, że palenie papierosów wpływa negatywnie na przebieg NChJ. Prawdopodobnie wiąże się to $z$ większym doświadczeniem życiowym lub też ze współistniejącymi chorobami.

6. Jak wynika z danych zawartych w niniejszej pracy, styl życia prowadzony przez badanych nie odbiega od wiedzy i jest prawidłowy. Styl życia chorych charakteryzuje się przestrzega- 
niem diety, znormalizowaną aktywnością życiową i ograniczeniem używek.

\section{Piśmiennictwo}

1. Bartnik W. Wytyczne postępowania w nieswoistych chorobach zapalnych jelit. Prz Gastroenterol. 2007; 2(5): 215-229.

2. Radwan P, Radwan-Kwiatek K, Skrzydło-Radomańska B. Rola mikroflory jelitowej $w$ nieswoistych zapaleniach jelit. Prz Gastreneterol. 2009; 4(1): 1-6.

3. Skrzydło-Radomańska B, Radwan P, Radwan-Kwiatek K. Czy Helicobacter odgrywa rolę w nieswoistych chorobach zapalnych jelit. Prz Gastroenterol. 2009; 4(4): 178-183.

4. Molenda M, Bober J, Stańkowska-Walczak D, Stańczyk-Dunaj M. Palenie papierosów czynnikiem sprzyjającym powstawaniu nieswoistych chorób zapalnych jelit. Rocz Pomor Akad Med. 2010; 56(3): 50-54.

5. Rosińska A, Więckowicz M, Cichy W. Wpływ nikotyny i innych składników dymu tytoniowego na przebieg nieswoistych zapaleń jelit u dzieci i dorosłych. Gastroenterol Pol. 2006; 13(20): 131-135.

6. Kotuła I, Kasicka-Jonderko A, Jonderko K. Nienowotworowe następstwa oddziaływania palenia papierosów na czynność układu trawiennego. Wiad Lek. 2004; 57(9-7): 473-479.

7. Kamrowska A, Kasprzak K, Marciniak J, Goch A, Kamrowski C. Lęk i depresja we wrzodziejącym zapaleniu jelita grubego i chorobie Leśniowskiego-Crohna. Pol Merk Lek. 2010; 28, 165(239): 239-241.

8. Paradowski L, Neubauer K, Kollbek P. Epidemiologia nieswoistych zapaleń jelit, skala problemu. Med Dypl. 2007; supl. 5-7: 33-37.

9. Milio N. Health through public policy. Ottawa 1986. Za: Ostrowska A (red.). Styl życia a zdrowie. Z zagadnień promocji zdrowia. Warszawa: IFiS PAN; 1999. 26.

10. Ostrowska A. Realizacja prozdrowotnego stylu życia w Polsce. W: Ostrowska A (red.). Styl życia a zdrowie. Z zagadnień promocji zdrowia. Warszawa: IFiS PAN; 1999. 33-120.
11. Neubauer K, Poniewierska E. Rola diety w nieswoistych zapaleniach jelit. Gastroenterol Pol. 2010; 17(1): 74-76.

12. Kargulewicz A, Stankowiak-Kulpa H, Grzymisławski M. Rola leczenia żywieniowego w chorobie Leśniowskiego-Crohna. Gastroenterol Pol. 2010; 17(4): 300-303.

13. Kamińska B, Landowski P. Rola wybranych czynników środowiskowych w etiopatogenezie nieswoistych zapaleń jelit. Forum Med Rodz. 2009; 3(1): 42-48

14. Kierkuś J, Szymańska E, Szymańska S, Kamińska E. Wpływ nieswoistych zapaleń jelit na ciążę i płodność - zasady postępowania, specyfika leczenia. Dev Period Med. 2013; 17, 1: 77-84.

15. Dobrowolska-Zachwieja A, Jakubowska-Burek L. Korzyści leczenia biologicznego u osób z nieswoistymi chorobami zapalnymi jelit. Prz Gastroenterol. 2010; 5(2): 68-76.

16. Perek M, Cepuch G. Poziom wiedzy i jakość życia młodzieży chorej na nieswoiste zapalenia jelit. Piel XXI w. 2011 2(35): 45-50.

Artykuł przyjęty do redakcji: 16.02.2016

Artykuł przyjęty do publikacji: 13.06.2016

Źródło finansowania: Praca nie jest finansowana z żadnego źródła. Konflikt interesów: Autorzy deklarują brak konfliktu interesów.

\section{Adres do korespondencji:}

Lucyna Gacek

ul. Jana Henryka Dąbrowskiego 79

60-959 Poznań

tel.: 618546864

e-mail: Igpoznan@02.pl

Pracownia Praktyki Pielęgniarskiej, Katedra Pielęgniarstwa

Uniwersytet Medyczny im. Karola Marcinkowskiego w Poznaniu 